\title{
CONSEQUENTIAL DAMAGES IN EMINENT DOMAIN IN PENNSYLVANIA.
}

The exercise of the power of eminent domain is the taking of private property for a public use. If we use the word "take" in its strictly narrow sense as meaning a dispossession, we will find that the damages inflicted by the excrcise of the power may be classified under the following headings:

A. Damages to the property actually taken by the exercise of the power, in which case we must distinguish between the taking of the whole and the taking of a part, and between damages caused by the construction and by the operation of the public use.

B. Damages to property not taken, caused by the taking of property in the vicinity, in which case the property may or may not abut upon the property taken, and where we must distinguish again between damages caused by the construction and damages caused by the operation.

C. Damages to-abutting and non-abutting owners caused by the disturbance of a public highway by (I) change of grade, (2) construction and operation of (a) the works of a private corporation, (b) of a sewer. This disturbance of the public highway may or may not involve the exercise of the power of eminent domain. Where there is merely a change of grade, there is no taking. When a private corporation occupies the highway, there sometimes is an additional servitude, and, to that extent, a taking. In this case, also, we must distinguish between damages caused by construction and damages caused by the operation of the public use. $B$. and $C$. are commonly referred to as consequential damages, and the distinction between them is of some practical importance.

The term "consequential," although deeply embediled in the law by constant use, is unfortunate in this connection because it has no bearing on the real distinction between these different kinds of damage. All damages are consequential in the proper sense of the word, that is, following upon the doing of the injurious act. The distinction between direct and consequential, if there be any, seems really to be a distinction between less and more remote damages. The distinction is entirely of fact, impossible of a rational definition, and involves a question, 
practical rather than theoretical, of where to stop in the chain of causation. A few instances of the different meanings attributed to the word "consecuuential" are collected in the note.

The distinction which has been drawn in the law of eminent domain between consequential and direct damage requires for its understanding some attention to a plase of the law which is now obsolete as a matter of practical importance. The constitutions of 1776,1790 and 1838 provided in language practically identical, ${ }^{2}$ at least no distinction has been drawn in this connection, that no man's property shall be taken for a public use withunt his consent or that of his representatives."

The constitutional provision was construed by the Supreme Court to impose a liability only for damage to the property

"The word "consequential" has been used as meaning (I) damages arising from the breach of covenants in a deed. Duncan, J., in Funk v. Voneida, II S. \& R. 109 at III (1824). (2) Damages to upper riparian owner on a canal caused by water raised by a dam. Frecland v. Railroad $\mathrm{C}_{0}, 66 \mathrm{~Pa}$. 91 $(18 ; 0)$. (3) Damages caused by diminishing flow of water in a private stream passing lower riparian owner. Lycoming Gas \& Water Co. Y. Moyer, $99 \mathrm{~Pa} .15$ (i\&82), scubblc. See Shenandoah Co.'s App., 2 W. N. C. 47 ( $18 ; 5)$, contra. (4) Damages arising from diversion of flow of surface water. Moser, J., in Stepp v. Lenger, 25 D. R. $4 \sigma_{3}$ (1916). In Pittsburg v. Scott, I Pa. 309 at 320 (1845), Rogers, J., said in speaking of damage done by a nuisance that a distinction was taken in England between direct and consequential damage, which distinction was repudiated here.

- “Nor shall any man's property be taken or applied to public use without the consent of his representatives and without just compensation being made." Art. 9, Sec. V, Constitution of 1;90; Art. 9, Sec. $\mathrm{X}$, Constitution of 1838 .

${ }^{3}$ Since the provisions in a State constitution are merely prohibitive and all powers not limited are left unaffected except in so far as is provided in the Federal constitution, as to which no question arises in this connection, it follows that under this clause the State can take for a private use withourt restraint. Although this argument was called to the attention of the Supreme Court, it did not prevail; see remarks of Gibson, C. J., in Harvey v. Thomas, Io W'atts 3 at 67 (1840); and the Court in effect amended the constitution by construing the provisions to altogether prohibit the taking for a private use. See remarks of Elkin, J., in Phila. Clay Co. v. Lork Clay Co., $241 \mathbf{P}_{2}$ 305 at 309 (1915). The provision also destroys the power of eminent domain altogether, because under it property could not be taken without the consent of the owner or his representatives. This, however, was entircly overlooked.

- For a history of the doctrine in Pennsylvania, see able opinion of Thayer, P. J., in Patent v. Railroad Co., 14 W. X. C. 545 (1884) at 547, ct scg.. where the learned judge pointed out that the doctrine originated in the case of Phila. and Trenton R. R. Co., 6 Whart. 25 (1840), where Chief Justice Gibson confined the meaning of the word "take" as used in the constitutional provision "that no man's property shall be taken . - 
taken, using the word "take" s as meaning an actual dispossession.

The legislature might, however, in authorizing the exercise of the power of eminent domain impose a greater liability for damage than that arising under the strict construction of the constitution which had been adopted, and such seems to have been the general practice.

without just compensation" to an actual seizure of property, and therefore when the injury extended only to the depreciation of the property without a taking, the constitution afforded no protection. As pointed out by Houston, J., dissenting in Monongahela Nav. Co. v. Coons, 6 W. \& S. Ior (1843), the clause in the Constitution of 1838 , which provided that every man, for an injury done him in his lands, goods, ctc., shall have a remedy by due course of law, was comprchensive enough to cover the plaintiff's case and confer the right to recover consejuential damages. Strangely enough, however, the argument of Gibson, C. J., prevailed, and the constitutional aspect of the law was not remedied until the adoption of the Constitution of 1874 Although the grounds of decision are not clearly indicated by Gibson, C. J., they were probably as follows: The clause prohibiting a taking without just compensation is merely prohibitive, and since a taking is a dispossession, there is nothing in the Constitution to prohibit an injury or destruction without just compensation.

- Mere putting on a plan or laying out of a street not a taking, District of City of Pittsburgh, 2 W. \& S. 320 (184r), see, however, Philadelphia Parkway, 250 $\mathrm{P}_{2}$. 257 (I915), even though by statute the owner cannot recover damages for the taking of buildings subsequently erected within the lines of the located strcet. Bush v. the City, $166 \mathrm{~Pa} .57$ (1895). Diminishing the flow of water in a private stream opposite the land of 2 lower riparian owner is a taking. Shenandoah Co.'s App., 2 W. N. C. 47 (1875); Lycoming Gas \& Water Co. v. Moyer, $99 \mathrm{~Pa}$. 615 (1882), semble, contra. In Dobbins v. Brown, $12 \mathrm{~Pa}_{2}$. 75 (1849), it was held that the covenant of general warranty was not broken by a taking in eminent domain for a public canal, since the eviction was not a dispossession, as it left a qualified use and possession in the owmer. Extension of cross arms of a telegraph pole across land is a taking. Young v. Electric Traction Company, $32 \mathrm{~Pa}$. C. C. R. 81 (1906). Closcly connected with the meaning of the word "take" is the conception of the nature of the estate in the land taken, acquired by the procecdings in eminent domain. As the statutes in eminent domain are generally silent as to the nature of the estate acquired, several theories have been advanced: (1) That the interest is an easemenl; if so, it must be an easement in gross, as there is no dominant tenement, and the entire fee of the soil must remain in the former owner during the existence of the easement in the public use. (2) That the estate is a modified fee. If so, it must be a determinable fee [sce Foulke, Rule Against Perpetuities in Perna. $(1909)$, Sec. 28$]$, and the entire ownership is vested in the public use, the former owner having only a possibility of reverter so long as the use exists. (3) If the statute so provides, the interest may be 2 fee simple absolute. Railroad Co. v. Bruce, $122 \mathrm{~Pa} .23$ (1883).

- "Notwithstanding, then, some prior difference of opinion, it may now be taken as the ascertained rule that the lawmakers may legally omit 2 provision for merely consequential damages, when creating a corporation to construct an improvement for the common benefit. But, I think, such was not the popular impression, and it is certain that, governed either by constitu- 


\section{Public Rivers.}

The title to the bed and waters of a public or navigable stream between low water marks is in the Commonwealth and the title of the riparian owners stops with this shore line. When the Commonwealth grants the right to use or obstruct such $a$. river, there is no exercise of the power of eminent domain hecause no private property it taken. ${ }^{\top}$ A number of these cases turning on riparian right's are frequently cited in discussions of consequential damages, although they strictly speaking, are not in point. Where the use which a riparian owner was making of a public stream was interfered with by anything done on the stream under grant from the Commonwealth, it was a case of dammum absque injuria, because the owner had no legal right in the stream. Thus it was held that a riparian owner could not recover damages for interference with a ford, ${ }^{8}$ fishery, ${ }^{9}$ spring

tional scruples or actuated by a sense of common justice, our legislature have always directed payment for consequential injuries suffered by the landholder from the making of public highways or other like works. I say always; for the very few instances where this has been omitted among the numerous acts of this character which load the statute books, scarcely deserve to be esteemed exceptions." Bell, J, in Mifflin v. Railroad Co., $16 \mathrm{P}_{2}$. 182 at 193 (185I). In these cases arising before the Constitution of 1874 , the liability for consequential damages was sustained on the language of the act of incorporation or act authorizing the doing of the act in question. Mifflin v. Railroad Co., I6 Pa. 182 (185I); Schuylkill Nav. Co. v. Loose, is $\mathrm{Pa}$. 15. (1852); Union Canal Co. v. Keiser, 19 Pa. 134 (1852) ; Buckwalter v. Bridge Co.. $38 \mathrm{~Pa}$. 281 (186r); Koch v. Water Co., $65 \mathrm{~Pa}$. 288 (1870); Baid Eagle Boom Co. v. Sanderson, 81 $1 / 2$ Pa. 402 (1876); Lycoming Gas \& Water Co. v. Moyer, $99 \mathrm{~Pa}$. 6r5 (r882).

There is language in the books from which it appears that it was supposed that the power of eminent domain was involved when the legislature granted rights in a public stream. Strong, J., in Clarke v. Bridge Co, $4 \mathrm{I} \mathrm{Pa}$. 147 at 158 (1862).

Zimmerman v. Union Canal Co., I W. \& S. 346 (I84r); statutory proceedings. The water from the ford was deepened by the construction of a dam under authority of an Act of Assembly.

- Shrunk v. Navigation Co., 14 S. \& R. 7r (1826); statutory proceedings. Fishery in Schuylkill River destroyed by construction of a dam lower down the river. Tinicum Fishing Co. v. Carter involved a fishery in the Delaware River and was an action on the case against another riparian owner for destroying the fishery by extending the wharf into the river under license from the port wardens. On the first appeal in 6I $\mathrm{Pa}$. 21 (1869) a verdict for the plaintiff for $\$ 1217$ reduced to $\$ 800$ was reversed, in an opinion by Sharswood, $\mathrm{J}$., principally on the ground that it was a case of damnum absque injuria. On second appeal, 6r $\mathrm{Pa}$. 35 ( 1870 ), a verdict for the plaintiff for $\$ 35$ was again reversed on the ground principally that the plaintiff could have no pre- 
situate below highwater mark, ${ }^{10}$ or a mill race, ${ }^{11}$ when the damage was caused by a corporation lawfully occupying the river under grant from the Commonwealth.

Where a traveler on a public river suffered damage by an obstruction in the river placed there under grant from the Legislature, he was not entitled to recover, ${ }^{12}$ unless liability was expressly imposed by the act authorizing construction of the bridge $^{13}$ or dam. ${ }^{14}$ Where, however, the obstruction was erected without authority of law there was a nuisance and a right of recovery accordingly. ${ }^{18}$

scriptive right in the fishery. On third appeal, in $77 \mathrm{~Pa} .310(1875)$, a verdict for the defendant was reversed, as the court below erred in holding that the evidence of the derivation of the plaintiff's title was insufficient, and on the fourth and final appeal. in $90 \mathrm{~Pa} .85$ (18;9), a verdict for the plaintiff for $\$ 426$ was again reversed on the same grounds substantially as laid down in the first appeal.

${ }^{10}$ Commonwealth v. Fisher, I P..\& W. 462 (1830); spring situate below high water mark on the Susquehanna River flooded because of the construction of the State Canal. See remarks of Thayer, P. J., in Patent v. The Railroad Co., I4 IW. N. C. 545 (1884) at 547.

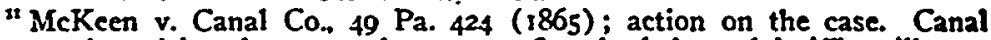
Company by raising dam caused water to flow back into plaintiff's mill race situate on the Lehigh River. The case is obscurely reported. A verdict for the plaintiff was affirmed. although the reasoning of the Court was against his right to recover. Aonongahela Navigation Co. v. Coons, 6 W. \& S. IOr (1843); action on the case. Plaintiff had erceted a mill in the Youghiogeny River under Dam Act of $180_{3}$ and was damaged by defendant's construction of a dam in the Monongahela River. The Act of 1803 , the Court said, merely gave the riparian owners a revocable license to erect dams. This seems to be the leading case on the question of exemption from liability for consequential damages, but does not exactly raise the point, as the plaintiff had no property right at all which was injured, and therefore the question of whether there was a constitutional liability for consequential damages was not reached in the case.

a In Monongahela Bridge Co. v. Kirk, $46 \mathrm{~Pa}$. Ir2 (1863), and Clarke v. Birmingham-Pittsburgh Bridge Co., 4I $\mathrm{P}_{2}$. 147 (1861), a navigator in the stream was held unable to rccover damages in an action on the case against the Bridge Co. for loss of a boat wrecked on the piers of the bridge, as the river was public and the property of the state. See, however, remarks of Thayer, P. J., in Patent v. The Railroad Company, 14 W. N. C. 545 (1884) at 547 .

2s Dugan v. Bridge Co., $27 \mathrm{~Pa} .303$ (1856).

"Bacon v. Arthur, 4 Watts 437 (1835).

${ }^{23}$ In Hughes v. Heiser, I Binney 463 (1808), the plaintiff was navigating a public river with rafts and was prevented from passing 2 certain point by a dam erected by the defendant. The case was, therefore, that of an obstruction of a public highway, as the dam was built contrary to law. The only point involved appeared to be whether the plaintiff had suffered such specin damage as entitled him to sue for damages caused by the nuisance. It was held that he could recover, as he had suffered special damage, and that it was immaterial whether it was immediate or consequential. 
In Malone v. The City, ${ }^{10}$ there was an action on the case against the City of Philadelphia to recover damage for the erection and maintenance of a sewer which carried sewage into the dock adjoining plaintiff's wharf, filling it up and making it unfit for navigation. The nonsuit was affirmed on appeal. The Act of February 25, $1861,{ }^{17}$ authorized councils to build the sewer into the Delaware River and the mouth of it went to low water line, beyond which plaintiff's title did not go, and consequently the nuisance was in a river which belonged to the Commonwealth, and for which the plaintiff could not recover. It was also said that a municipal corporation was not liable for consequential damages to private property unless the liability was imposed by statute. ${ }^{18}$

\section{Adjolning Owners Prior to 1874.}

An adjoining owner whose land was not taken had no right to recover damages for injuries inflicted $1, y$ the corporation exercising the power of eminent domain on his neighbor's land in the absence of negligence or of a statutory provision imposing the liability.

In Railroad Co. v. Young, ${ }^{19}$ a riparian owner brought an action on the case against the railroad company to recover damages arising from the construction of defendant's railroad along the bank of the Susquehanna River. The railroad company cut into a bluff on one side of the river, and had to construct an embankment out into the stream thus diverting a portion of the water from the plaintiff's mill which was situated below on

$1{ }^{2}$ Penna. 370 (1882).

"1" P. L. 43.

1" The following cases, although frequently cited, contain only dicta as to consequential damages: Reitenbaugh v. R. R. Co., 21 Pa. 100 (1853). Statutory proceedings under Act of 1849 to assess damages for the construction of a railroad. Woodward, $J$, in the Supreme Court, said, at p. 105, "What damage is to be considered consequential and not direct is a question which the adjudiged cases must answer, and which I will not discuss here because it docs not arise out of the report before us." Yealy v. Fink, $43 \mathrm{~Pa}$. 212 (1862), trespass against township-supervisors personally. Judgment for defendants, as they were not personally liable for damages caused by acts done- honestly in excrcise of the discretion given them by law.

${ }^{13} 33$ Pa. 175 (1859). 
the same side of the river. The plaintiff had a right to erect the mill dam in a navigable stream under the Act of March 23, $1803,{ }^{20}$ and did not own the land where the cutting took place. The defendant was a foreign railroad company acting under authority of the Act of February 16, 1841. ${ }^{21}$ A verdict for the plaintiff was reversed on appeal as the plaintiff's claim was not for the taking but for the consequential injury for which the defendant was not liable under the Act of Assembly. Furthermore, the plaintiff had, under the mill dam act, only a license which the state had the right to revoke. Since in this case the plaintiff had no right upon which to found his action, the decision does not clearly raise the point. It is useful, however, as it illustrates the proposition involved. In Canal.Co. v. Mulliner, ${ }^{22}$ the plaintiff brought an action on the case against the canal company for damages caused by the flooding of his cellar and injury to the walls of the house because the defendants raised the water of the canal, and it was held that he could not recover in the absence of negligence or wantonness.

\section{Damages to Rest of Tract Where Part is Taken.}

We shall now consider the case where part of a tract is taken, which generally occurs where there is a right of way of a railroad or a public road. In these cases the court considers the tract as a whole and endeavors to ascertain what damage is inflicted upon it by the taking of the part, and in doing this uses as a measure of damage the difference in market value of the whole tract as affected by the construction and as unaffected by the construction. Strictly speaking, however, this principle does not touch the real issue. The corporation takes a strip of land and that particular strip only is taken, and the first inquiry probably is-what damages are caused by the taking of that strip of land, that is, what is that strip of land worth, what is the basis upon which ordinary men

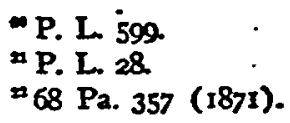


would consider the matter if a sale were being made of the strip and the compulsory taking in eminent domain is nothing more or less than a compulsory sale. In addition to this damage caused by the taking, there are damages inflicted upon the rest of the tract of land. These damages are damages to land not taken and are really and strictly speaking consequential damages. The circumstance, however, that they are consequential damages has been overlooked.

In Watson v. Railroad $\mathrm{Co}_{0 .}{ }^{23}$ the court said that the damage was to the tract as a whole, even though part was occupied, and the charter in the case at bar directed the viewers to estimate "the in jury or damage sustained," and to take into consideration the advantages that would be derived by the owner from the railroad. "The inconvenience arising from division or from increased difficulty of access and the cost of additional necessary fencing are alike the direct and immediate result of the construction of the road."

In Gilmore v. Railroad Co., ${ }^{24}$ proceedings were had under the Act of February I9, $1849,{ }^{25}$ to assess damages for the construction of a railroad. Evidence offered to cover the following points was held properly ruled out: ( 1 ) that the premises had been endangered by fire; (2) that the property is endangered by fire; (3) that since the road was opened the fence on each side has repeatedly been on fire; (4) that the jury may not give damages for any probable accidents or fires in the future. It was held, however, that all the injuries may be considered which would result probably and naturally from the reasonable and usual operation of the road. ${ }^{26}$ The court also held that damages could be recovered for destruction to growing crops planted between location and construction, although with knowledge of the property owner.

- 37 Pa. 469 at $480-81$ ( $186 \mathrm{r}$ ).

* 104 Pa. 275 (1883).

* P. L. 79.

* The reference by the court to the provisions of Art. 16, Sec. 8 , seems to have nothing to do with the case. 
In Railroad Company v. Hummel, ${ }^{27}$ in statutory proceedings to assess damages for the taking of part of a tract for the right of way for a railroad, the jury of view included an item of damage which might arise from accidental fire in the ordinary operation of the road excluding damage from carelessness. On appeal the judgment was reversed so far as it confirmed the report as to this item.

\section{Damages to Abutting and Non-Abutting Owners by Dis- turbance of Public Highway.}

We shall next consider the case of damages to abutting and non-abutting owners by disturbance of a public highway, the only two instances of which coming within the scope of the discussion were, (a) construction and operation of a railroad, (b) change of grade.

The law was that a railroad company lawfully occupying a public street was not liable for damages to abutting property owners in the absence of negligence and any statutory provision imposing a liability. It was held that there was no taking of land even if the abutting owners owned the bed of the street in fee; that the legislature merely authorized a change in the mode of the use of the street, and it was a case of damnum absque injuria. 28

The Act of February 19, 1849, 20 under which railroads generally have been and are still constructed, provides that when the company shall locate its road in and upon any street or alley in a city or borough, compensation shall be made to abutting

$=27$ Pa. 99 (1850).

* Phila. \& Trenton R. R. Co., 6 Whart. 25 (1840), statutory proceedinge to assess damages. Exceptions to report of viewers that they refused to hear evidence of damages to private property owners (probably refers to abutting owners) by reason of the location of the road, were dismissed. In Mercur $r$. Railroad Company, $36 \mathrm{~Pa}, 99$ (1859), and Faust v. Railroad Company, 3 Phila. 164 (1858), s. C. 25 L. F. 221, bill of abutting owner for an injunction was dismissed. Snyder v. Railroad Company, $55 \mathrm{~Pa} .340$ (1867), statutory proceedings, report of viewers awarding damages to abutting owners set aside on exceptions. The defendant moved its tracks in the street nearer to plaintiff's house. Struthers y. Railroad Company, $87 \mathrm{Pz} 282$ (1874), trespass on the case; judgment for the defendant.

- P. L.'79 Sec 10 . 
owners for damages caused by any excavation or embankment made in the construction of the road. ${ }^{30}$ The same Statute ${ }^{31}$ also provides that the railroad may occupy the whole of a country road upon constructing a new one in its stead. ${ }^{32}$

In case of special charters provision was frequently made as to occupancy of streets and duty of the railroad. ${ }^{33}$

It was clearly the law, prior to the Constitution of 1874 , that a city or borough changing the grade of a road incurred no liability for damages to the abutting owner, in the absence of statutory provision, ${ }^{34}$ and that a private corporation changing the grade of a street was in like manner exempt. ${ }^{35}$

\section{Constitution of 1874 and Its Affect.}

The Constitution of 1874 , Article 16 , Section 8 , provides as follows:

"Municipal and other corporations, and individuals invested" with the privilege of taking private property for public use, shall make just compensation for property taken, injured, ${ }^{37}$ or destroyed

- Railroad Company y. Rose, $74 \mathrm{~Pa} .362$ (1873) ; Railroad Company v. McChesney, 85 Pa. 522 (1878) ; Railroad y. Rhoadarmer, I07 Pa. 214 (1884); Duke v. Railroad Company, I29 Pa. 422 (1889); Seipel v. Railroad Company, 129 Pa. 425 ( 1889 ).

"See. 13.

"As to which see Philips v. the Railroad Company, $78 \mathrm{~Pa} .177$ (1875), where ejectment was brought by an abutting owner for the bed of a road occupied by the tracks and abandoned. Sugar Creek Township v. Railroad Company, $242 \mathrm{~Pa} .573$ (1914).

${ }^{*}$ See charter referred to in Mercur v. The Railroad Company, $36 \mathrm{~Pa} .99$ at 102 (1859).

"Green v. Borough of Reading, 9 Watts 382 (1842), probably the first case. O'Conner v. Pittsburgh, $18 \mathrm{~Pa}$. 187 (1851); In re Ridge Street, $29 \mathrm{P2}$. 391 ( I857).

${ }^{2}$ Henry v. Bridge Company, 8 W. \& S. 85 (1844).

* As to the application of the section to corporations created before its adoption, see Railroad Co. v. Patent, 17 W. N. C. 198 (1885); 2ffd. s. C. 14 W. N. C. 545 (1848); Railroad Co. v. Duncan, III P2. 352 (1886).

"In Edmundson v. The Railroad Company, III Pa. 316 (1885), where the company acquired the right of way by deed and it" was held that they were not liable for negligence of an independent contractor in construction of the works. Gordon, J,, at 320, said: "The words 'injured or destroyed," as found in this section, as everyone knows, was not designed to change, alter, or limit the nature and effect of corporate contracts, but to impose on those having the right of eminent domain a liability for consequential damages 
by the construction or enlargement of their works, highways or improvements, which compensition slall be paid or secured before such taking, injury or destruction. The General Assembly is hereby prohibited from depriving any person of an appeal from any preliminary assessment of damages against any such corporations or individuals, made by views or otherwise; and the amount of such damages, in all cases of appeal, shall, on the demand of either party, be determined by a jury, according to the course of the common law."

Municipal and other corporations and individuals vested with the power to take private property for public use are subject to the liability imposed by the clause. It is only necessary for the Legislature to grant the power of eminent domain in order that the Constitution may apply. It was only corporations, etc., invested with the power of eminent domain who were exempt from the ordinary rule of liability before and it was therefore only necessary to specify them. The Commonwealth is obviously invested with the power of eminent domain as part of its sovereignty, but is probably not liable under this section as it nuay not be sued without its consent. No decision on the

from which they have been previously exempt. If. a natural person, in the excrcise of a right on his own land, cut off the water of a creek or other stream, from his neighbor below, or backed it upon his neighbor above, or if in the lawful use of a highway, such person by any means injured the property of an adjacent owner, he was responsible for the damages; but previous to the present constitution, a corporation possessing the right of eminent domain was not so liable. To create a liability for injuries of this kind, and to make corporations responsible for such damages, was the object, and the only object, of the section under discussion. This is obvious enough from the concluding words thercof, "which compensation shall be paid or secured before such taking, injury, or destruction," for though consequential injuries may be anticipated and compensated, those or'yinating from carelessness or neglect, as they cannot be foreseen, neither can the damages resulting from them be in advance measured or provided for." Paxson, C. J., in Kailroad Company v. Walsh, $124 \mathrm{~Pa}$. 544 at 558 (1889), said: "Our latest case is P. R. R. v. Marchant, in which it was held that the word 'injury' (or injured) as used in Sec. 8, Art. 14, of the Constitution means such a legal wrong as would be the subject of an action for damages at common law, that for such injuries both corporations and individuals now stand upon the same plane of responsibility." Gordon, J., in Railroad Company v. Lippincott, II6 I'a. 472 at 483 (1897), said: "We agree that over and beyond the damages which arise from a taking of property, whether in the shape of land or a right, the cunstitution does impose on corporations a direct responsibility for every injury for which a natural person would be liable at common law. so we have held in the case of E.dmundson v. Railroad Co., III Pa. 316 ( 1885 ), and to this doctrine we adhere." 
point has been found. A county is liable under this clause in the Constitution. ${ }^{38}$

Boroughs are invested with the power of eminent domain and are clearly subject to the provisions of the section. In Borough of Strasbury $\times$ Bachman, ${ }^{3 \mathrm{sa}}$ an urdinance was passed by the burough authorizing the street committee to cut drains across private property near streets and prescribing a penalty upon any uwner who should stop up a drain so cut. The defenclant was sucd for violating tic ordinance and a verdict for him was affirmed on appeal. The court said that the ordinance was invalicl in violatiun Article 16 , Sec. 8 , because it contained no provision for compensation for property injured. ${ }^{39}$

Townships not having the power of eminent domain were held :x(mpt from liability for damages for change of grade, ${ }^{304}$ but are now liable under Act of May 28, 1913.40 Townships might just as well have been brought within the clause by simpiy vesting them with a power of eminent domain. In the case of Marshall v. Township of Lower Towamensing, 12 an action of trespass $q$. c. $f$. was brought against a township for damages caused by the supervisors entering on the plaintiff's land and taking gravel for the construction of a road, no payment or security being made or given. The court entered judgment for the defendant and wrote a very obscure opinion. The case seems to decide that entry of the supervisors was not illegal, and therefore trespass $q$. $c$. $f$. would not lie, but that the township would be liable for the gravel taken anyway, under Article 16, Sec. 8 of the constitution. The remedy against the town-

"Counity of Chester v. Brown, $117 \mathrm{~Pa} .647$ (1888), action of trespass, affirming I $\mathrm{Pa}$. C. C. I ( 1885 ), overruling dictum of Elwell, $J$, in Freeze v. Columbia County, 6 IV. N. C. I45 at I47 (1879).

$28=2$ I W. N. C. $462(1887)$.

- It was contended in one case, without success, however, and so held by the court below, that a borough was not liable for consequential damages because it was not under any statute invested with the power of eminent domain. Hendrick's App., $103 \mathrm{~Pa} .358$ (1883), grounds of reversal not clear.

sa Wagner v. Salzberg Township, $132 \mathrm{~Pa} .636$ (1890); Shoe v. Township, 31 Pa. Super. Ct. 137 (1896).

10 P. L. 368. This act is retrospective. Miller v. Township, $42 \mathrm{~Pa}$. C. C. R. 579 (I914).

${ }_{11}^{12}$ W. N. C. 235 (1883). 
ship, therefore, probably was by an action of trespass on the case, yet we have seen that townships were not liable for consequential damages.

$A$ bill for an injunction against threatened consequential damage will be clismissed, ${ }^{42}$ as the liability imposed by the constitution is for an actual physical injury and not for a threatened in jury. An injunction may, however, issue to restrain the prosecution of the work until compensation has been paid or secured.

IVe propose now to consider the effect of the Constitution of 1874 upon the liability for the different kinds of damages mentioned at the beginning of this article. ${ }^{13}$ The somewhat peculiar case of interference with the use of a public river already referred to should first be disposed of.

\section{Public River Cases Since 1874.}

The cases since the Constitution of 1874 are as follows: In Railroad Company v. Jones, ${ }^{14}$ the plaintiff had in 1863 been granted a right to a ferry across a public river. The defendant railroad company constructed a bridge which interfered with access to the landing from the ferry, which landing, appears to have been situate in a public street; the plaintiff also introduced evidence to show that he had leased a portion of the bank of the river for his landing. It

- Delaware County's App., I19 Pa. 159 (1888). In this case 2n injunction was refused to restrain county commissioners from the erection of 2 new bridge wholly within the lines of the old bridge and a public roadway. Plaintiff alleged that the bridge was being constructed in 2 manner that would be injurious to his right. Patterson's App., $129 \mathrm{P2}, 109$ (1889). In this case a preliminary injunction was dissolved, as it did not appear how the vlaintiff was injured.

* For convenience of reference the classification will be repeated here.

(A) Damages to the property actually taken by construction and operation-taking of whole, taking of part.

(B) Damages to property not taken caused by taking in the vicinity -construction and operation.

(C) Damages to abutting and non-abutting owners by disturbance of a public highway.

r. Change of grade.

2. Construction and operation of the works of a corporation.

3. Construction of sewers.

"III Pa. 204 (1885). 
was held, in an action on the case, that the plaintiff could recover as lessee the depreciation in the market value of the lease for the landing, but could recover nothing for the injury to the ferry franchise or for interference with the landing on a public street. In neither of which latter cases did Article 16, Section 8 apply, because no wrong was done the plaintiff as he had no legal right either to the ferry or the use of the street.

In Butcher's Ice \& Coal Company v. Philadelphia, ${ }^{\text {is }}$ a riparian owner on the Delaware River recovered damages in an action of trespass under Article 16, Section 8, for interference with the use of his wharf caused by deposits from a sewer constructed by the defendant. In this case there was an interference with the riparian use of the bank, which is and always has been private property. A riparian owner has the same right of access to the stream as an abutting owner on a street has to the highway.

In Walmut Street Bridge, Philadelphia's Appeal, ${ }^{46}$ the City - of Philadelphia constructed a bridge across the Schuylkill River on the line of Walnut Street in such a way as to destroy all access to the wharf of a riparian owner by masted vessels. In statutory proceedings the jury of view found that the property had been depreciated in market value by the construction of the bridge. Exceptions to the report of the viewers were dismissed by the court, which ruling was on appeal, confirmed. The Supreme Court held that the acts of February $7,1818,47$ and of April 9, $1835,{ }^{48}$ conferred upon private riparian owners the right to construct wharves upon banks of the Delaware and Schuylkill rivers within the city limits, by which acts a private right of property was conferred which could not be invaded by the commonwealth or city without compensation being made; that since the adoption of the Constitution of 1874 a mere injury conferred a right to compensation, and that the facts in the present case showed a substantial injury.

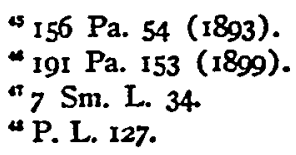


In Frecland v. Railroad Company, ${ }^{48 *}$ the title of the riparian owner between high and low water mark was interfered with by the construction of the railroad on the other side, changing the course of the stream. The recovery in trespass was allowed without any discussion of the form of action or of consequeritial damages.

No other case since the Constitution of 1874 has been found. In the case of Railroad v. Jones, ${ }^{40}$ where the property owner had no legal right in the river, it was held that he was not protected by Article 16, Section 8, of the Constitution. In the other two cases, ${ }^{50}$ the property owner had a legal right in the bank of the river which was injured by the construction of the works complained of.

\section{Damages to Property Actually Taken.}

Where the whole tract is taken, no question arises. The damages are simply the market value of the property at the time of the taking. Where a part only is taken, there is an element of damage to the part not taken, which may be properly called consequential. All such damages were, however, generally recoverable before the Constitution of 1874 , as we have seen; under legislative provisions and under the application of the rule of law fixing the measure of damages, which is the difference between the value before and after the taking. In the application of this rule, the law takes into consideration many elements of damage to the rest of the tract which may properly be called consequential. It will be noted that in this case, in the case of railroad companies, damages are recoverable arising from the operation of the road."

*e $197 \mathrm{~Pa} .529$ (F901).

- Irr P2. 204 (1885).

* Butcher's Coal Co. v. Phila., 156 Pa. 54 (1893); Walnut Street Bridge, Phila.'s App., 191 P2. 153 (I899). In Freeland v. Railroad Company, $197 \mathrm{~Pa}_{2}$. 529 (IgOr), the question was not discussed.

- Baker v. Railroad Company, $236 \mathrm{~Pa} .479$ (1912). The consideration of all the items cognizable in such cases lics outside the scope of this discussion. The case of damage from operation is referred to for the sake of pointing out the distinction in such cases between the damages to the rest of the land on one hand, and on the other, damage to adjoining and abutting owners in streets. 
The distinction between the case where there is a taking of part of the property, and the damage to the rest is to be considered, and the case where the damage is to land no part of which is taken, must be carefully borne in mind. There are several cases in which this distinction does not at first clearly appear and are likely to give trouble unless carefully examined.

In Northern Central Railroad Co. v. Holland, 52 the railroad company occupied a strip of ground between the plaintiff's house and the street. The plaintiff had a right of way over this strip of ground to the street. The building of the road destroyed or materially interfered with the easement, and such interference was unquestionably a taking in the strict sense, and therefore let in the question of damages to the rest of the tract, that is, the tract of ground to which the right of way was appurtenant. In this view of the case the objection that there could be no recovery in an action of trespass was probably well taken. ${ }^{.3}$ The damages from noise and smoke, therefore, were considered in this case because there was a taking of part of the tract injured, to wit, the appurtenant right of way.

In Snyder v. Lancaster, ${ }^{54}$ the chief damage to the plaintiff's lot was caused by the removal of an adjoining house, which removal was caused by the opening of a street. There were proceedings before the viewers, and it was held that the entire damages to the plaintiff's lot were to be considered. The opening of the street took off the rear end of the lot, and consequently there was a taking of part of the tract injured.

\section{(To be continued.)}

\section{Philadelphia.}

$$
\text { Roland R. Foulke. }
$$

$$
\text { * } 117 \text { P2. 6r3 (1888). }
$$

The language of the court below, on p. 621, in charging the jury, puts the case very well, as follows: "They are liable to this action on the case for interruption of easements and for consequential damages arising therefrom, and for the inconveniences and annoyances of the noise and smoke, and cinders, and dangers to ingress and egress from proximity under the circumstances of this case as elements of damage, in the depreciation of the value of the property."

$\because 20$ W. N. C. $184(1887)$. 